\title{
Wpływ wydatku tłoczenia cieczy przemywającej na stopień oczyszczenia przestrzeni pierścieniowej
}

\begin{abstract}
Cementowanie rur okładzinowych jest jednym z najważniejszych etapów podczas wykonywania otworu wiertniczego. Zaczyn cementowy wypełnia i uszczelnia przestrzeń pomiędzy kolumną rur okładzinowych a formacją geologiczną otaczającą otwór wiertniczy. Niekompletna izolacja strefowa i/lub słabe uszczelnienie pomiędzy rurami okładzinowymi, płaszczem cementowym a formacją skalną może powodować niekontrolowane przepływy mediów złożowych, ograniczając potencjał eksploatacyjny otworu wiertniczego. Niedostateczne usunięcie pluczki bądź osadu pozostałego po płuczce wiertniczej może prowadzić do komplikacji podczas zabiegu cementowania poprzez powstawanie kanałów płuczki w cemencie. W celu zapewnienia skutecznego związania rur okładzinowych z formacją geologiczną za pomocą zaczynu cementowego, płuczka wiertnicza oraz osad powstały na ścianie otworu muszą zostać całkowicie usunięte. Jako środek zapobiegawczy najczęściej stosuje się wtłaczanie przed zaczynem cementowym cieczy przemywających i buforowych, które wpływają na oczyszczenie przestrzeni pierścieniowej oraz pozwalają uzyskać dobre związanie cementu ze skałą. W artykule przedstawiono wpływ wydatku tłoczenia cieczy przemywającej na stopień oczyszczenia przestrzeni pierścieniowej otworu wiertniczego. Na podstawie pomiaru wydatków tłoczenia możliwe było określenie stopnia oczyszczenia przestrzeni pierścieniowej z osadu płuczkowego. Badania zostały przeprowadzone dla różnych wartości wydatku przy stałym czasie kontaktu cieczy ze skałą. Testy wykonano przy użyciu wody jako wzorcowej cieczy przemywającej, natomiast osad płuczkowy utworzono z płuczki potasowo-polimerowej. Badania wpływu wydatku tłoczenia cieczy przemywającej na stopień oczyszczenia przestrzeni pierścieniowej były przeprowadzone na rdzeniach piaskowca, które umieszczono w specjalnie skonstruowanym urządzeniu. Analiza uzyskanych wyników badań laboratoryjnych umożliwiła wytypowanie odpowiednich wydatków tłoczenia cieczy przemywającej, pozwalając na właściwe oczyszczenie przestrzeni pierścieniowej otworu wiertniczego z osadu płuczkowego. W wyniku przeprowadzonych badań laboratoryjnych wytypowano wydatki tłoczenia cieczy przemywającej, przy których uzyskano najlepsze usunięcie osadu płuczkowego ze ściany otworu wiertniczego, co znajduje przełożenie na skuteczne związanie rur okładzinowych z formacją skalną.
\end{abstract}

Słowa kluczowe: wydatek tłoczenia, przemywki, ciecze przemywające, oczyszczenie przestrzeni pierścieniowej.

\section{Influence of the flow rate of the preflush fluid on the effectiveness of the purification of the annular space}

Cementing is one of the most important steps in well construction. Cement slurry fills and seals the annular space between the casings and geological formation surrounding the well. Incomplete zone isolation can cause gas leakage, oil spills and reduce the potential exploitation of the well. Non-removal of the mud cake or drilling fluid from the borehole wall can lead to channeling in the cement sheath. In order to ensure effective bonding of the casing with the geological formation by cement slurry, the drilling fluid and mud cake formed on the wall of the borehole must be removed completely. As a precautionary measure, washes and spacers are pumped into the hole before the cement slurry. Preflushes prepare the annulus for the upcoming cement placement and affect the cleaning of the annular space from the drilling mud and allow good bonding of the cement to the rock. The article presents the effect of the flow rate of the preflushes on the degree of purification of the annular space of a borehole. Depending on the flow velocity, it was possible to determine the degree of purge of the annular space from the filter cake. Laboratory tests were carried out for different fluid velocities at a steady preflushes contact time with the rock. Tests performed using water as a standard wash, while the filter cake was formed from a polymer-potassium mud. The study of the influence of the flow rate of the preflushes on the degree of purification of the annular space was carried out on sandstone cores which were placed in a specially constructed device. Interpretation of the obtained results allows to identify the appropriate flow rate of the preflushes allowing proper cleaning of the annular space of the borehole from the filter cake. As a result of laboratory tests, the flow rate of the preflushes was selected for the best removal of the filter cake from the borehole wall, which is reflected in the effective bonding of the casing with the rock formation.

Key words: flow rate, wash fluid, preflush fluid, cleaning of the annular space. 


\section{Wprowadzenie}

Podczas zabiegu cementowania do przestrzeni pierścieniowej zatłacza się sekwencję płynów w celu wyparcia płuczki wiertniczej i przygotowania przestrzeni pomiędzy rurami okładzinowymi a formacją skalną dla umieszczenia zaczynu cementowego. Po przewierceniu interwału, w otworze prowadzi się cyrkulację płuczki w celu wyniesienia zwiercin na powierzchnię. Następnie z otworu wyciąga się przewód wiertniczy, podczas gdy obieg płuczki może być kontynuowany. W dalszych pracach przerywa się cyrkulację płuczki, w otworze wiertniczym prowadzi się pomiary geofizyczne, a później zapuszcza rury okładzinowe oraz wznawia obieg płuczki wiertniczej. Płuczka wiertnicza posiada właściwości dostosowane do warunków otworowych w czasie wiercenia, które niekoniecznie będą efektywnie wpływać na jej odpowiednie usuwanie w czasie wytłoczenia $\mathrm{z}$ otworu $[4,17,19]$. $\mathrm{Z}$ tego względu wymagana jest odpowiedna obróbka płuczki, tzn. modyfikowanie jej właściwości reologicznych.

Po zapuszczeniu rur okładzinowych i obróbce płuczki wiertnicznej, do otworu wtłacza się ciecze wyprzedzające, których zadaniem jest przygotowanie przestrzeni pierścieniowej przed cementowaniem. Dlatego też powinny one spełniać szereg wymagań $[15,17,18]$, tj.:

- muszą pozostawiać nawilżoną kolumnę rur okładzinowych oraz formację skalną, w celu polepszenia wiązania cementu,

- powinny być wtłaczane z zachowaniem przepływu turbulentnego, aby poprawić skuteczność usuwania płucz$\mathrm{ki}$, lecz bez powodowania powstawania szczelin $\mathrm{w}$ formacji (co może się zdarzyć, jeśli wydatek tłoczenia, a zatem ciśnienie w otworze wiertniczym stanie się nadmiernie wysokie) oraz bez doprowadzenia do niedopuszczalnego uszkodzenia formacji,

- należy tak wtłaczać je do otworu, aby zapewnić wystarczający czas kontaktu pomiędzy cieczą wyprzedzającą a powierzchnią w przestrzeni pierścieniowej, w celu poprawiania usunięcia płuczki i oczyszczenia ścian otworu z osadu wytworzonego przez płuczkę wiertniczą,

- muszą zapewniać najbardziej skuteczne wypieranie płuczki z przestrzeni pierścieniowej,

- powinny być łatwe do usunięcia z przestrzeni pierścieniowej przez wtłaczany zaczyn cementowy.

Ciecze wyprzedzające są zwykle podzielone na przemywki (nieobciążone ciecze) oraz bufory (obciążone ciecze) (rysunek 1). Przemywki posiadają właściwości reologiczne cieczy newtonowskich, których gęstość i lepkość jest bardzo zbliżona do wody. Przemywki powodują na ogół rozcieńczanie lub dyspergowanie płuczki. Z uwagi na ich niską lepkość są szczególnie przydatne przy wytłaczaniu w przepływie turbulentnym. Celem stosowania przemywek jest oczyszczenie po- wierzchni przestrzeni pierścieniowej z płuczki i poprawa stanu związania zaczynu cementowego $\mathrm{z}$ formacją skalną i rurami $[12-14,17]$. Parametry technologiczne tych cieczy muszą być bardzo precyzyjne zaprojektowane. Najprostszą przemywką jest woda, lecz w celu lepszego rozcieńczenia i zdyspergowania płuczki stosuje się chemiczne przemywki, które stanowią mieszaninę rozpuszczalników oraz środków powierzchniowo czynnych. Środki powierzchniowo czynne nie tylko przyczyniają się do rozcieńczenia płuczki, ale powodują wzrost zwilżalności powierzchni rur okładzinowych, dzięki czemu wzrasta przyczepność, a także stopień związania zaczynu cementowego z rurami okładzinowymi [12, 17, 18].

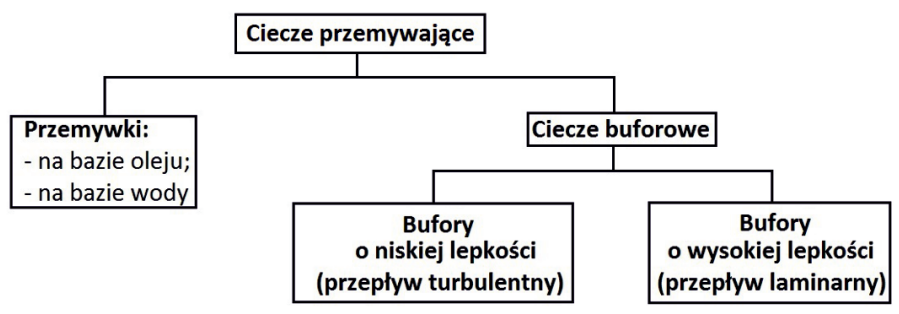

Rys. 1. Klasyfikacja cieczy przemywających [12]

Jedną z kluczowych właściwości cieczy wyprzedzającej jest jej kompatybilność z zaczynem cementowym i płuczką wiertniczą. Kompatybilność dwóch cieczy oznacza, że właściwości reologiczne ich mieszaniny znajdują się między tymi, które występują w poszczególnych cieczach [19]. Po zmieszaniu razem, dwie niekompatybilne ciecze (np. zaczyn cementowy i płuczka wiertnicza) mogą spowodować osadzanie cząstek stałych, flokulacje, oddzielanie cieczy itp.

Przepływ i wypieranie płuczki wiertniczej z przestrzeni pierścieniowej podczas zabiegu cementowania są kluczowymi czynnikami, które decydują o szczelności płaszcza cementowego podczas eksploatacji otworu. Nieskuteczne wyparcie

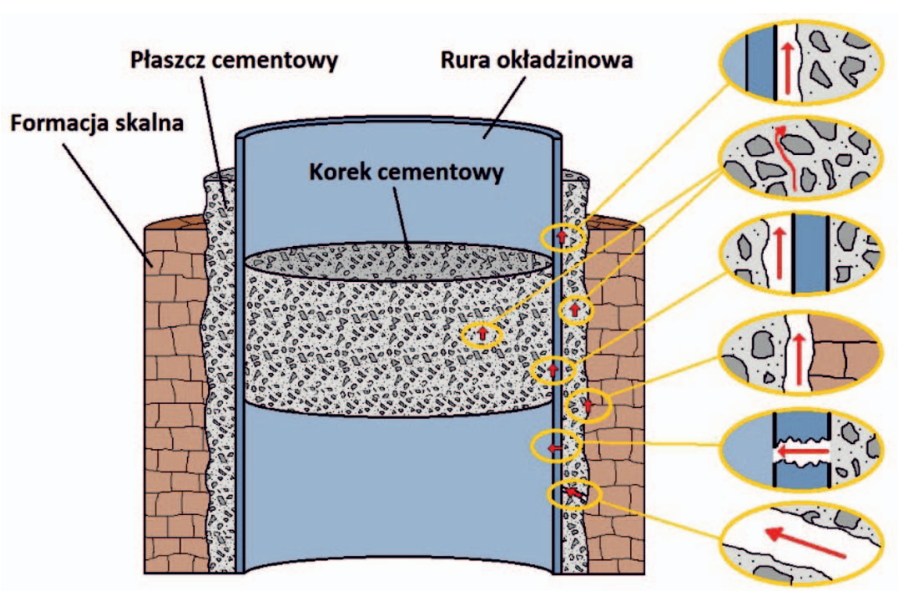

Rys. 2. Drogi migracji w zacementowanym otworze wiertniczym [9] 
płuczki z przestrzeni pierścieniowej może spowodować powstawanie migracji gazu (rysunek 2). Konsekwencjami niewłaściwie przeprowadzonych prac związanych z cementowaniem może być korozja lub uszkodzenie rur okładzinowych oraz ostatecznie wzrost kosztów związanych z ponownym cementowaniem. Dlatego poprawa jakości wypierania płuczki z przestrzeni pierścieniowej i odpowiednie wtłoczenie zaczynu cementowego w przestrzeń pierścieniową podczas cementowania ma zasadnicze znaczenie w konstrukcji otworu wiertniczego [9-11, 22].

\section{Badania laboratoryjne}

W artykule zamieszczono wyniki badań wypływu wydatku tłoczenia cieczy przemywającej na stopień oczyszczenia przestrzeni pierścieniowej otworu wiertniczego. Podczas badań laboratoryjnych stosowano próbki piaskowca pobranego z głębokości 300 $\div 400 \mathrm{~m}$. Użyte w trakcie badań laboratoryjnych próbki zostały wycięte w kształcie walca o średnicy zewnętrznej $25 \mathrm{~mm}$ i długości $60 \mathrm{~mm}$ (fotografia 1).

Rdzenie piaskowca umieszczono w specjalnie skonstruowanym statywie (fotografia 2, rysunek 3) znajdującym się wewnątrz rury w aparaturze badawczej.

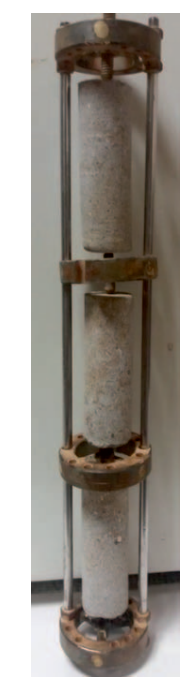

Fot. 2. Rdzenie piaskowca w statywie
Skonstruowane urządzenie (rysunek 4, fotografia 3) składa się z pompy z wirnikiem (1) zanurzanej w zbiorniku z wybraną cieczą wiertniczą (płuczka lub przemywka) (2), napędzanej silnikiem elektrycznym (3) poprzez pasek klinowy (4), rury wykonanej z PVC (5), wewnątrz której na specjalnym statywie (6) umieszcza się trzy rdzenie piaskowca, węża odprowadzającego pluczkę wiertniczą (wodę) (7) do zbiornika. Silnik, pompa oraz rura $z$ PVC są przymocowane do dwóch statywów (8) zapewniających stabilność urządzenia. Przepływ odbywał się w obiegu zamkniętym.

Badania wykonano dla różnych wydatków tłoczenia cieczy przemywającej przy stałym czasie kontaktu tej cieczy ze skałą. Testy przeprowadzono dla wybranej cieczy przemywającej (woda) oraz dla płuczki potasowo-polimerowej. Stopień oczyszczenia przestrzeni pierścieniowej określono na podstawie pomiarów zmiany

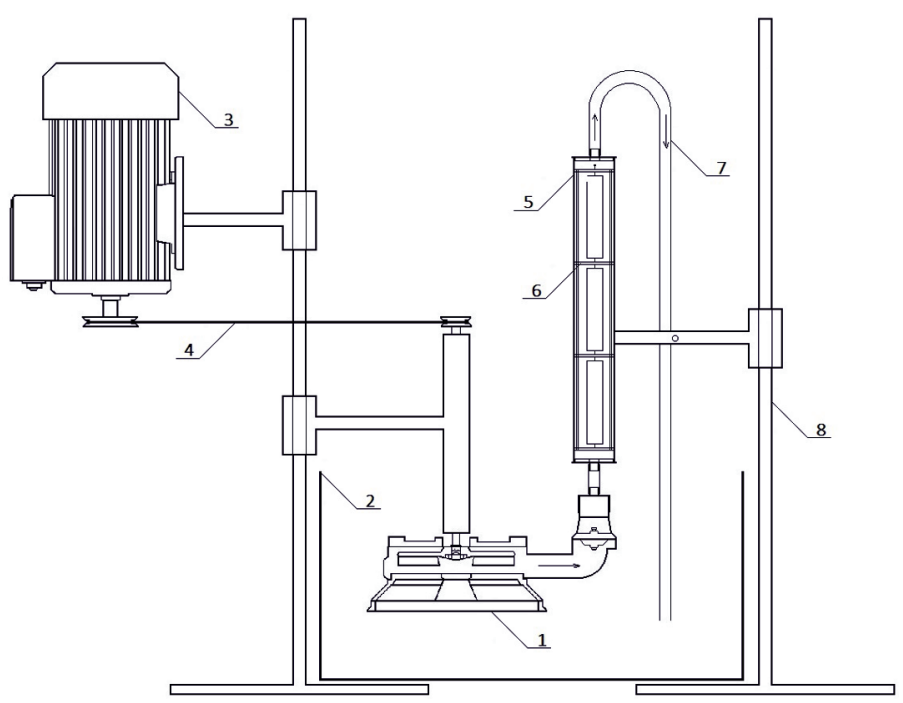

Rys. 4. Schemat aparatury badawczej

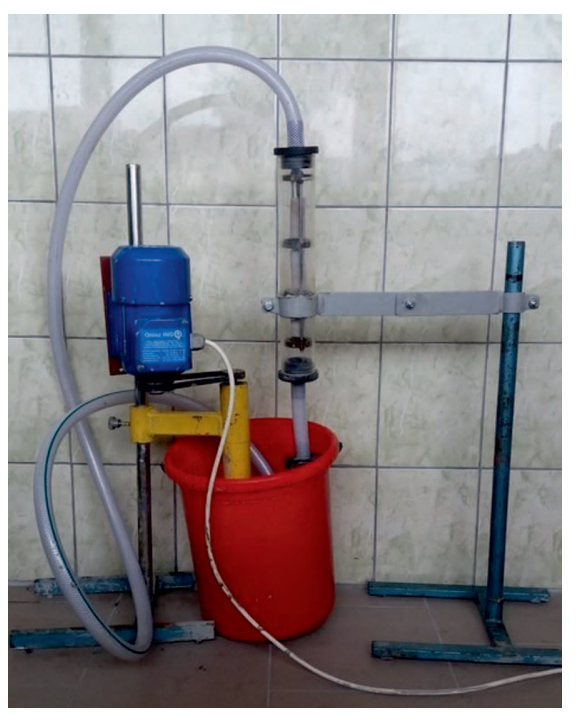

Fot. 3. Urządzenie do symulowania przepływu cieczy wiertniczych

przyczepności na kontakcie stwardniały zaczyn cementowy-skała (po wykonaniu przemywania). W badaniach wykorzystano płuczkę otworową i zaczyn cementowy zastosowane podczas realizacji otworu wiertniczego $\mathrm{P}-2 \mathrm{~K}$.

Pierwszym etapem przeprowadzonych badań laboratoryjnych było wytworzenie na rdzeniach piaskowca osadu płuczkowego. Tworzenie osadu polegało na obmywaniu w ciągu godziny trzech rdzeni umieszczonych w skonstruowanym urządzeniu przez przepływającą płuczkę. Wydatek tłoczenia płuczki został określony na podstawie wstępnych prób i obserwacji prowadzonych podczas testów przygotowujących próbki rdzeni do badań. 
W kolejnym etapie prowadzono przemywanie rdzeni cieczą przemywającą przez cztery minuty dla sześciu wybranych wydatków tłoczenia: 9,4;11,2;13,2;14,8;16,0 oraz 17,0 1/min. Od wydatku o wartości 11,2 1/min następowała zmiana z przepływu laminarnego na turbulentny. Oczyszczone z osadu rdzenie przygotowano do kolejnego etapu badań, których celem było określenie efektywności uszczelnienia przestrzeni pierścieniowej na kontakcie stwardniały zaczyn cementowy-skała. Badania te przeprowadzono, opierając się na pomiarze przyczepności stwardniałego zaczynu cementowego do próbki skały. Rdzenie umieszczono centralnie wewnątrz pierścienia z tworzywa sztucznego (fotografia 4a), a następnie zalewano je przygotowanym zaczynem cementowym (fotografia 4b).
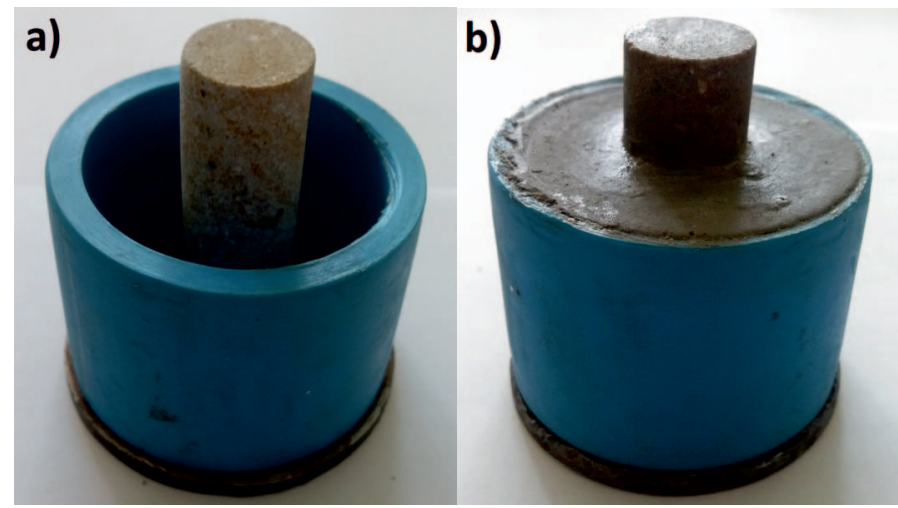

Fot. 4. Próbka do badań przyczepności na kontakcie stwardniały zaczyn cementowy-skała

Następnie próbki sezonowano w temperaturze $25^{\circ} \mathrm{C}$ w środowisku wodnym przez dwa dni. Po sezonowaniu umieszczano je między dwiema płytami maszyny wytrzymałościowej (fotografia 5), gdzie zmierzono siłę zerwania przyczepności na kontakcie stwardniały zaczyn cementowy-skała pod wpływem obciążenia przykładanego na próbkę.

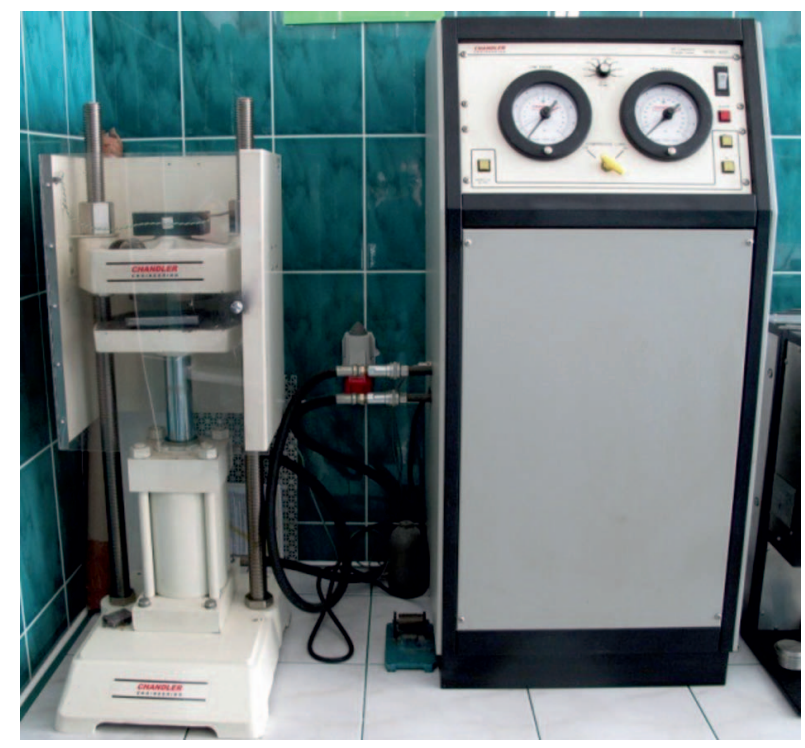

Fot. 5. Maszyna wytrzymałościowa
Po każdym pomiarze siły potrzebnej do zerwania przyczepności pomiędzy stwardniałym zaczynem cementowym a skałą, należało obliczyć przyczepność wyrażoną w MPa, według wzoru (1):

$$
\sigma_{p}=\frac{P}{S} \cdot 10^{-3}[\mathrm{MPa}]
$$

gdzie:

$P$ - siła nacisku powodująca zerwanie połączenia stwardniałego zaczynu cementowego ze skałą [kN],

$s$ - powierzchnia styku próbki skały ze stwardniałym zaczynem cementowym $\left[\mathrm{m}^{2}\right]$.

Siłę nacisku $(P)$ odczytywano bezpośrednio ze wskaźnika maszyny wytrzymałościowej, natomiast powierzchnia styku skały ze stwardniałym zaczynem cementowym wynikała $\mathrm{z}$ geometrii form, w których rdzenie były zalewane zaczynem cementowym.

Z rysunku 5 można odczytać wymiary potrzebne do obliczenia powierzchni styku skały ze stwardniałym zaczynem cementowym.

Są to:

- średnica rdzenia $(d): 25 \mathrm{~mm}=0,025 \mathrm{~m}$,

- wysokość zacementowanej części rdzenia $(h)$ : $44 \mathrm{~mm}=0,044 \mathrm{~m}$.

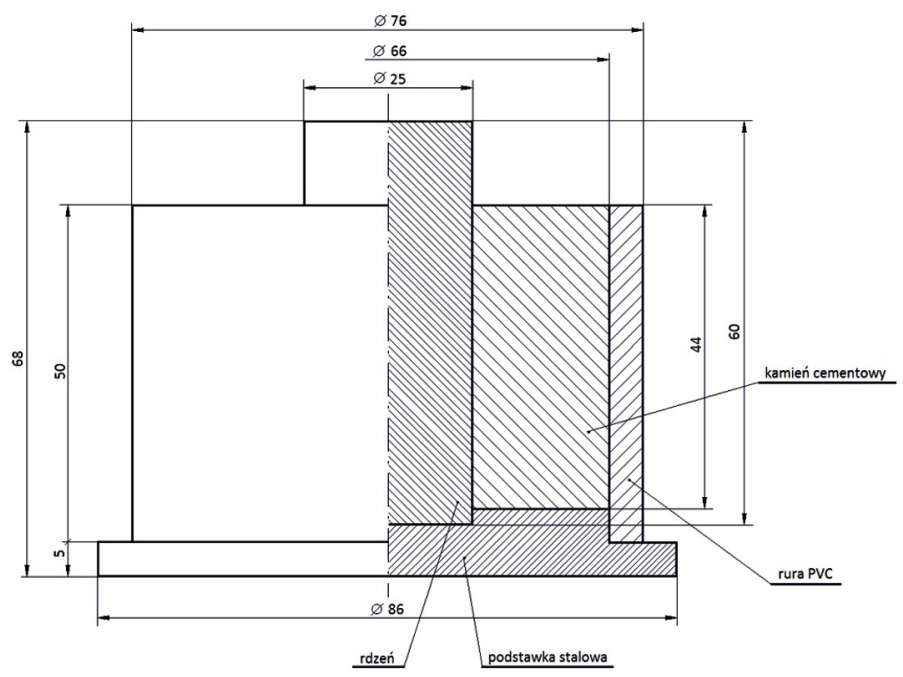

Rys. 5. Półprzekrój formy [9]

$$
s=\pi \cdot d \cdot h
$$

$$
s=\pi \cdot 0,025 \cdot 0,044=0,003456\left[\mathrm{~m}^{2}\right]
$$

stąd przyczepność na kontakcie stwardniały zaczyn cementowy-skała, $\sigma_{p}$, wyznaczono za pomocą wzoru [9]:

$$
\sigma_{p}=\frac{P}{0,003456} \cdot 10^{-3}=\frac{P}{3,456}[\mathrm{MPa}]
$$




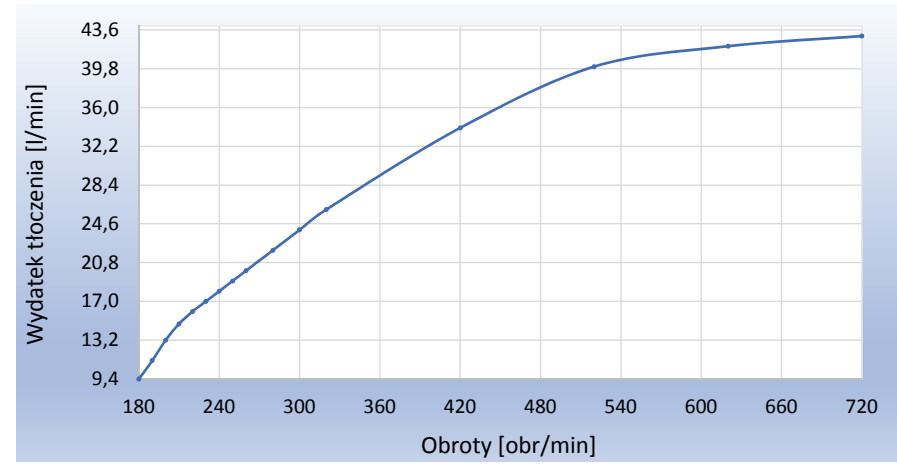

Rys. 6. Charakterystyka pompy

Na rysunku 6 zamieszczono charakterystykę zastosowanej pompy tłoczącej ciecz przemywającą.

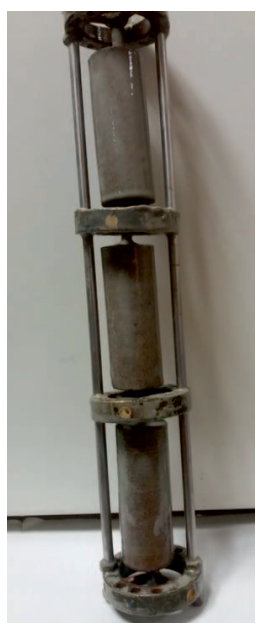

$9,4[1 / \min ]$

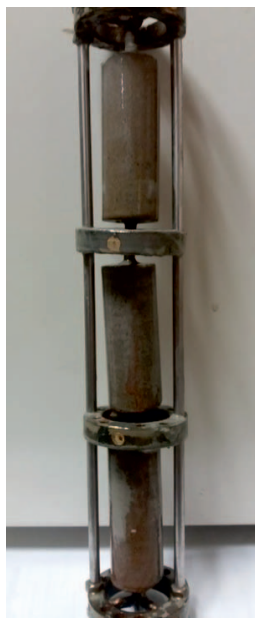

$14,8[1 / \mathrm{min}]$

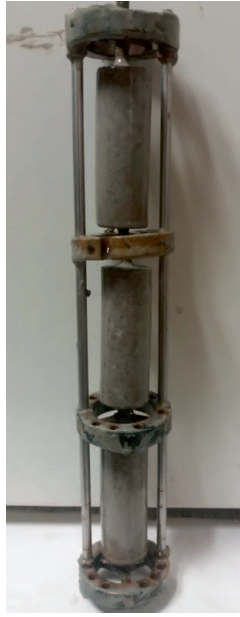

$11,2[1 / \mathrm{min}]$

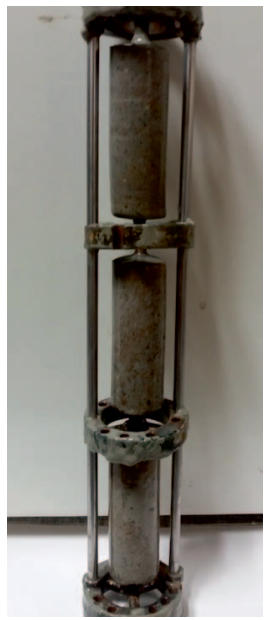

$16,0[1 / \mathrm{min}]$

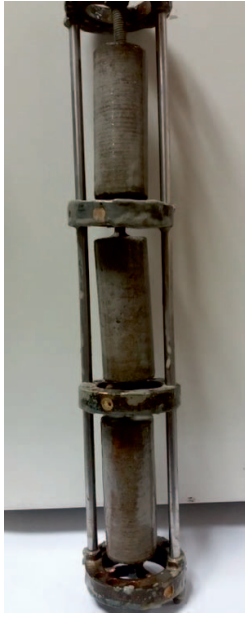

$13,2[1 / \mathrm{min}]$

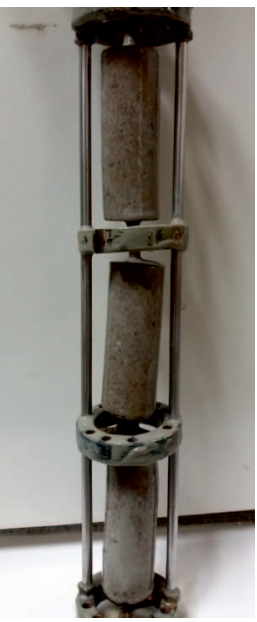

$17,0[1 / \mathrm{min}]$
Fot. 6. Rdzenie piaskowca przemyte z osadu płuczkowego za pomoca wody

Najważniejszym badaniem, pozwalającym określić wpływ płuczek wiertniczych na jakość zacementowania, było badanie przyczepności na kontakcie stwardniały zaczyn cementowy-skała. Wyznaczono przyczepność bazową (lub inaczej
Tablica 1. Bazowa przyczepność na kontakcie stwardniały zaczyn cementowy-skała

\begin{tabular}{|c|c|c|}
\hline & $\begin{array}{l}\text { Siła zerwania } \\
\text { przyczepności }\end{array}$ & $\begin{array}{l}\text { Przyczepność na kontak- } \\
\text { cie stwardniały zaczyn } \\
\text { cementowy-skała }\end{array}$ \\
\hline & {$[\mathrm{kN}]$} & {$[\mathrm{MPa}]$} \\
\hline Próbka bazowa & 8,2 & 2,37 \\
\hline $\begin{array}{l}\text { Próbka z osadem } \\
\text { bez przemywania }\end{array}$ & 2,1 & 0,61 \\
\hline
\end{tabular}

przyczepność odniesienia), do której porównywano wyniki kolejnych badań (tablica 1). W celu jej określenia rdzenie wycięte $\mathrm{z}$ piaskowca zostały zalane zaczynem cementowym, $\mathrm{z}$ pominięciem etapu przemywania w cieczy przemywającej. Następnie wyznaczono przyczepność na kontakcie zaczyn cementowy-skała dla rdzeni przemytych wodą. Przemyte rdzenie zostały zalane zaczynem cementowym. Skład i parametry zaczynu cementowego zamieszczono w tablicy 2.

Tablica 2. Skład i parametry zaczynu cementowego zastosowanego w badaniach

\section{Skład zaczynu}

Woda wodociągowa

Odpieniacz

$\mathrm{w} / \mathrm{c}=0,45$

Dodatek upłynniający

$0,5 \%$

Dodatek antyfiltracyjny $\quad 0,2 \%$

Chlorek wapnia $\quad 4,0 \%$

Chlorek potasu (bwow) $\quad 3,0 \%$

Lateks $\quad 10,0 \%$

Stabilizator lateksu $\quad 1,0 \%$

Mikrocement $\quad 10,0 \%$

Cement CEM I 32,5R $\quad 100 \%$

Dodatek spęczniający $\quad 0,3 \%$

\section{Parametry zaczynu cementowego}

Gęstość $\left[\mathrm{g} / \mathrm{cm}^{3}\right] \quad 1,78$

Odstój wody [\%] $\quad 0,0$

Rozlewność [mm] 240

\section{Odczyty z aparatu Fann}

\begin{tabular}{|c|c|c|c|c|c|c|c|c|}
\hline Temperatura & 600 & 300 & 200 & 100 & 60 & 30 & 6 & 3 \\
\hline $25^{\circ} \mathrm{C}$ & 187 & 105 & 74 & 44 & 27 & 17 & 6 & 4 \\
\hline
\end{tabular}

\begin{tabular}{|c|c|c|c|}
\hline \multirow{2}{*}{ Czas gęstnienia [h:min] } & \multirow{2}{*}{$\begin{array}{l}25^{\circ} \mathrm{C} \\
5 \mathrm{MPa}\end{array}$} & $30 \mathrm{Bc}$ & $2: 55$ \\
\hline & & $100 \mathrm{Bc}$ & $3: 32$ \\
\hline Początek wiązania [h:min] & \multirow{4}{*}{$25^{\circ} \mathrm{C}$} & \multicolumn{2}{|c|}{$4: 46$} \\
\hline Koniec wiązania [h:min] & & \multicolumn{2}{|c|}{$5: 35$} \\
\hline Filtracja $\left[\mathrm{cm}^{3} / 30 \mathrm{~min}\right]$ & & \multicolumn{2}{|c|}{36,0} \\
\hline $\begin{array}{l}\text { Wytrzymałość na ściskanie po } \\
2 \text { dniach [MPa] }\end{array}$ & & \multicolumn{2}{|c|}{10,6} \\
\hline
\end{tabular}

Po sezonowaniu próbek przez dwa dni w środowisku wodnym przeprowadzono badania przyczepności, rezultaty zamieszczono w tablicy 3 oraz na rysunku 7. 


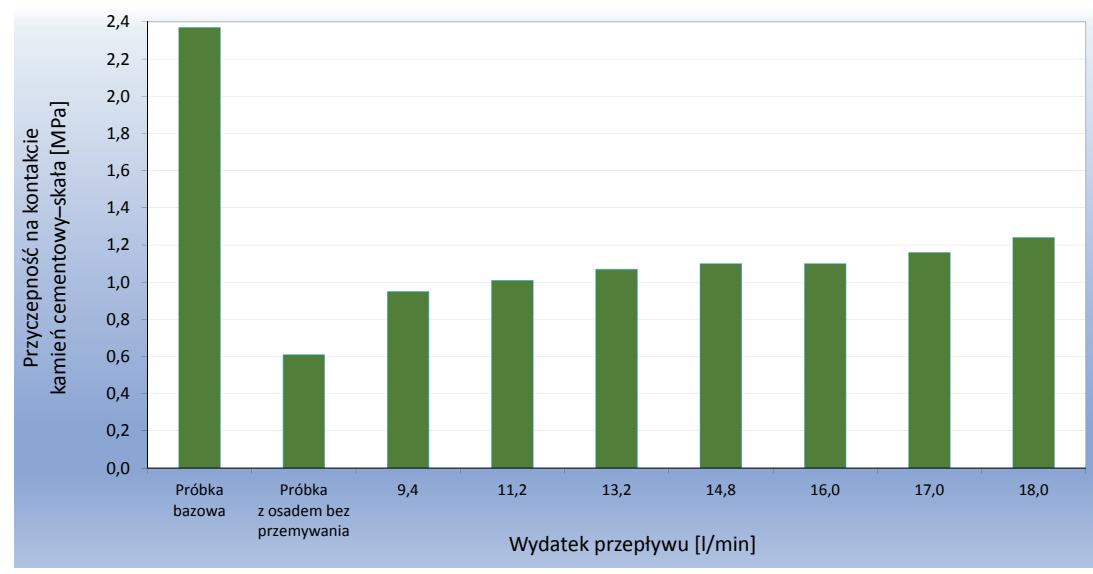

Rys. 7. Przyczepność na kontakcie stwardniały zaczyn cementowy-skała dla próbek przemywanych cieczą o różnym wydatku tłoczenia (czas kontaktu: cztery minuty)

Wartości przyczepności uzyskanej po przeprowadzeniu badań przemywania rdzeni piaskowca z osadu płuczkowego dla różnych wydatków tłoczenia cieczy przemywającej wynosiły od $0,95 \div 1,16 \mathrm{MPa}$, co stanowiło około $40 \div 50 \%$ wartości bazowej. W stosunku do rdzenia piaskowca bez działania cieczy przemywającej uzyskano wzrost przyczepności od 56 do $90 \%$. Na podstawie uzyskanych wyników można za- obserwować, że wzrost wydatku tłoczenia cieczy przemywającej powoduje zwiększenie przyczepności na kontakcie stwardniały zaczyn cementowy-skała.

Celem badań było określenie wpływu wydatku tłoczenia cieczy przemywającej na stopień oczyszczenia przestrzeni pierścieniowej otworu wiertniczego. W zależności od wydatków tłoczenia możliwe było określenie stopnia oczyszczenia przestrzeni pierścieniowej z osadu płuczkowego na podstawie pomiaru przyczepności na kontakcie stwardniały zaczyn cementowy-rdzeń skalny. Analiza uzyskanych wyników badań laboratoryjnych umożliwia wytypowanie odpowiednich wydatków tłoczenia cieczy przemywającej, co umożliwia właściwe oczyszczenie przestrzeni pierścieniowej otworu wiertniczego z osadu płuczkowego.

W wyniku przeprowadzonych badań laboratoryjnych wytypowano wartości wydatków tłoczenia cieczy przemywającej, pozwalające na usunięcie osadu płuczkowego ze ściany otworu wiertniczego, w celu poprawy związania rur okładzinowych z formacją skalną.

Tablica 3. Przyczepność na kontakcie stwardniały zaczyn cementowy-skała dla różnych wydatków tłoczenia cieczy przemywającej przy czasie kontaktu cztery minuty

\begin{tabular}{|c|c|c|c|c|}
\hline $\begin{array}{c}\text { Wydatek tłoczenia } \\
\text { cieczy przemywającej }\end{array}$ & $\begin{array}{c}\text { Siła zerwania } \\
\text { przyczepności }\end{array}$ & $\begin{array}{c}\text { Przyczepność na kontakcie } \\
\text { stwardniały zaczyn } \\
\text { cementowy-skała }\end{array}$ & $\begin{array}{c}\text { Procentowa zmiana przy- } \\
\text { czepności w stosunku do } \\
\text { przyczepności bazowej }\end{array}$ & $\begin{array}{c}\text { Procentowa zmiana przy- } \\
\text { czepności w stosunku do } \\
\text { próbki bez przemywania }\end{array}$ \\
\hline$[1 / \mathrm{min}]$ & {$[\mathrm{kN}]$} & {$[\mathrm{MPa}]$} & $\downarrow 60 \%$ & $\uparrow 56 \%$ \\
\hline 9,4 & 3,3 & 0,95 & $\downarrow 57 \%$ & $\uparrow 66 \%$ \\
\hline 11,2 & 3,5 & 1,01 & $\downarrow 55 \%$ & $\uparrow 75 \%$ \\
\hline 13,2 & 3,7 & 1,07 & $\downarrow 54 \%$ & $\uparrow 80 \%$ \\
\hline 14,8 & 3,8 & 1,10 & $\downarrow 54 \%$ & $\uparrow 80 \%$ \\
\hline 16,0 & 3,8 & 1,10 & $\downarrow 51 \%$ & $\uparrow 9 \%$ \\
\hline 17,0 & 4,0 & 1,16 & & $\uparrow$ \\
\hline
\end{tabular}

\section{Wnioski}

Na podstawie przeprowadzonych badań można wyciągnąć następujące wnioski:

1. Wartości przyczepności na kontakcie stwardniały zaczyn cementowy-skała, uzyskane dla różnych wydatków tłoczenia cieczy przemywającej, wynosiły $0,95 \div 1,16 \mathrm{MPa}$, co stanowiło około $40 \div 50 \%$ wartości bazowej.

2. W stosunku do rdzenia piaskowca bez działania cieczy przemywającej uzyskano wzrost przyczepności od 56 do 90\%.
3. Wzrost wydatku tłoczenia cieczy przemywającej do pewnej granicy powoduje zwiększenie przyczepności na kontakcie stwardniały zaczyn cementowy-skała.

4. Dobór odpowiedniego wydatku tłoczenia dla określonej powierzchni przestrzeni pierścieniowej wpływa na oczyszczenie otworu wiertniczego z osadu filtracyjnego pozostawionego przez płuczkę, co znajduje przełożenie na skuteczne związanie zaczynu cementowego do formacji skalnej. 
Artykuł powstał na podstawie pracy badawczej pt.: Analiza możliwości poprawy oczyszczenia przestrzeni pierścieniowej otworu wiertniczego przed zabiegiem cementowania - praca INiG - PIB na zlecenie MNiSW; nr zlecenia: 58/KW/17, nr archiwalny: DK-4100/45/17 oraz pracy własnej pt.: Wpływ wydatku tłoczenia cieczy przemywajacej na stopień oczyszczenia przestrzeni pierścieniowej - nr zlecenia: INiG 1896/KW.

\section{Literatura}

[1] Bowman G.R., Sherer B.: How to run and cement liners. World Oil 1988, s. 38-46.

[2] Braghini A. et.al.: Effect of rheology on flow displacement during cementing process in oil wells. $13^{\text {th }}$ Brazilian Congress of Thermal Sciences and Engineering, Uberlanda, MG, Brazylia 2010.

[3] Brice Jr. J.W., Holmes B.C.: Engineered casing cementing programs using turbulent flow techniques. SPE 1964, s. 503-508.

[4] Clark C.R., Carter L.G.: Mud displacement with cement slurries. J. Pet. Tech. 1973, s. 775-782.

[5] Crinklemeyer O.W., Puntney A.W., Sharpo J.R.: Use of water base spacer with thixotropic cement systems improves cement jobs. SPE 6367, 1976.

[6] Crook R.J., Keller S.R., Wilson M.A.: Deviated wellbore cementing: part 2 - solutions. JPT 1987, s. 961-966.

[7] Evanoff J.I., Cook Jr. C.: Optimizing cement design for improved job results. SPE 17441, 1988, s. 389-398.

[8] Haut R.C., Crook R.J.: Primary cementing: the mud displacement process. SPE 8253. Presented at the SPE Annual Technical Conference and Exhibition, Las Vegas, Nevada, 23-26.09.1979.

[9] Jasiński B.: Ocena wpływu cieczy przemywajacej na jakość zacementowania rur $w$ otworze wiertniczym po użyciu pluczki glikolowo-potasowej. Nafta-Gaz 2016, nr 6, s. 413-421, DOI: 10.18668/NG.2016.06.04.

[10] Kremieniewski M.: Proces migracji gazu w trakcie wiazania zaczynu cementowego. Nafta-Gaz 2011, nr 3, s. 175-181.

[11] Kremieniewski M., Rzepka M.: Przyczyny i skutki przepływu gazu w zacementowanej przestrzeni pierścieniowej otworu wiertniczego oraz metody zapobiegania temu zjawisku. Nafta-Gaz 2016, nr 9, s. 722-768, DOI: 10.18668/NG.2016.09.06

[12] Lavrov A., Torsaeter M.: Physics and mechanics of primary well cementing. Springer, 2016, s. 25-61.

[13] Li L., Alegria A. Doan A.A., Kellum M.G.: A novel spacer system to prevent lost circulation in cementing applications. AADE-16-FTCE-13. Presented in 2016 AADE Fluids Technical Conference and Exhibition, Houston, Texas, 12-13.04.2016.

[14] Li L., Padilla F., Doan A.A, Kellum M.G.: Evaluation of a new spacer system mixed on-the-fly. AADE-16-FTCE-51. Presented in 2016 AADE Fluids Technical Conference and Exhibition, Houston, Texas, 12-13.04.2016.

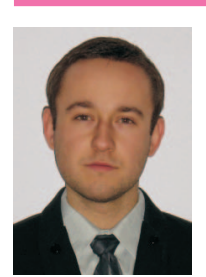

Dr inż. Marcin KREMIENIEWSKI

Adiunkt w Zakładzie Technologii Wiercenia.

Instytut Nafty i Gazu - Państwowy Instytut Badawczy

ul. Lubicz 25 A

31-503 Kraków

E-mail: marcin.kremieniewski@inig.pl
[15] Martin M., Latil M., Vatter P.: Mud displacement by slurry during primary cementing jobs - predicting optimum conditions. SPE 7590. Presented at the $53^{\text {rd }}$ Annual Fall Technical Conference and Exhibition of the Society of Petroleum Engineers of AIME, Houston, Texas, 1-3.10.1978.

[16] McLean R.H., Manry C.W., Whitaker W.W.: Displacement mechanics in primary cementing. SPE 1488, 1966.

[17] Nelson E.B. et al.: Well cementing. Schlumberger Educational Service, Houston, Texas, USA 1990.

[18] Sauer C.W.: Mud displacement during cementing: a state of the art. JPT 1987, s. 1091-1101.

[19] Shadravan A., Tarrahi M.: Agile data-driven fluid design: predicting the properties of drilling, spacer and cement slurry fluids. AADE-16-FTCE-07. Presented in 2016 AADE Fluids Technical Conference and Exhibition, Houston, Texas, 12-13.04.2016.

[20] Shahriar A.: Investigation on rheology of oil well cement slurries. PhD Thesis, The University of Western Ontario, London, Ontario, Canada 2011.

[21] Smith D.K.: Cementing. SPE Monography 1986, conference materials.

[22] Uliasz M., Zima G., Błaż S., Jasiński B.. Ocena właściwości cieczy wiertniczych $w$ aspekcie zapobiegania migracji gazu w otworach na przedgórzu Karpat. Nafta-Gaz 2015, nr 1, s. 11-17.

[23] Zuiderwijk J.J.M.: Mud displacement in primary cementation. SPE 4830, 1974.

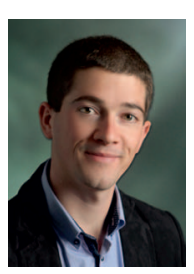

Mgr inż. Miłosz KĘDZIERSKI

Specjalista inżynieryjno-techniczny w Zakładzie

Technologii Wiercenia.

Instytut Nafty i Gazu - Państwowy Instytut Badawczy ul. Lubicz $25 \mathrm{~A}$

31-503 Kraków

E-mail: milosz.kedzierski@inig.pl

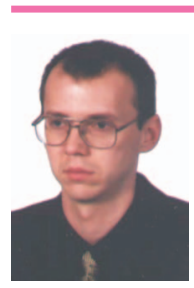

Dr inż. Marcin RZEPKA

Kierownik Laboratorium Zaczynów Uszczelniających w Zakładzie Technologii Wiercenia.

Instytut Nafty i Gazu - Państwowy Instytut Badawczy

ul. Lubicz 25 A

31-503 Kraków

E-mail: marcin.rzepka@inig.pl 